$14^{\text {th }}$ Conf. Agric. Develop. Res., Fac. of Agric., Ain Shams Univ., March, 2019, Cairo, Egypt

Special Issue, 27(1), 853 - 860, 2019

Website: http://strategy-plan.asu.edu.eg/AUJASCI/

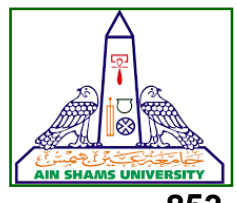

\title{
ROLE OF POLLINATORS ON EGYPTIAN CLOVER POLLINATION WITH SPECIAL REFERENCE TO HONEYBEE AT SOHAG GOVERNORATE, EGYPT
}

Zidan E.W. ${ }^{1}$, Abd El-latif A.M. ${ }^{2}$ and Mazeed A.R. ${ }^{1}$

1. Bee Research Dept., Plant Protection Res. Institute, Agric. Res. Center, Dokki, Giza, Egypt.

2. Forage Research Dept., Field Crops Res. Institute, Agric. Res. Center, Giza, Egypt.

*Corresponding author: ar.mazeed@gmail.com

Received 3 March, 2019, $\quad$ Accepted 27 March, 2019

\section{ABSTRACT}

Data revealed that Egyptian clover were visited by 22 genus of arthropods belong to 16 families and 7 orders. The identified species were classified to phytophagous, Nectarivore, predatory insects. During both seasons Apis mellifera L. and Megachile sp. were the most abundant pollinators detected at the first week of May till the end of flowering season in mid-June. The highest activity period for $A$. mellifera was detected at 11:00 am. However, the lowest activity was found at 3:00 pm. and 5:00 pm. in both seasons, respectively, with insignificant difference between them in the first season. Whereas the highest activity period for Megachile sp. was detected at 1:00 pm. and the lowest activity was found at 7:00 am. During both seasons. The free pollination treatment produced the highest mean number of seeds per head followed by the caged with honeybees followed by the caged without honeybees treatment with average $(48.15,43.85$ and 13.20 seeds /head) and (51.10, 46.10 and 10.85 seeds /head) during 2017 and 2018 seasons, respectively. The caged plants without honeybees produced the low weight of 1000 seed. Whereas the non-caged treatment produced the highest weights with an average $(2.75$ and $2.55 \mathrm{~g})$ and $(3.50$ and $3.90 \mathrm{~g})$ during both seasons, respectively.

Keywords: Egyptian clover, Seed yield, Pollinators, Bees.

\section{INTRODUCTION}

Egyptian clover (Berseem) Trifolium alexandrinum L. is a winter annual legume of major importance to Egyptian agriculture as a principle source of forage and for conserving soil fertility under intensive cropping (Bakheit, 2013). It's considered a source of protein, phosphorus, calcium, and other minerals for animals and a source of nectar and pollen for bees so that it has played a key role in the development of meat, milk, poultry, beekeeping and related industries (Jat et al 2014a). In Egypt, clover is a major seed export crop, annual export of clover seed have to more than 12000 tons in 2001 and the main honey producing crop (El-Nahrawy, 2005).

Nearly $75 \%$ of the world's flowering plants are dependent on insects for pollination (Bezabih and Gebretsadikan, 2014). The western honey bee, Apis mellifera L., is the premier managed pollinator in the United States; the value of its contribution to agriculture in the form of providing pollination services to over 90 crop species exceeds $\$ 14$ billion annually (Morse and Calderone, 2000).

Forage crops are absolutely dependent on insect pollination (Klein et al 2007). Egyptian clover reported to be highly self-incompatible (Jat et al 2014a). In most cases, honeybees' colonies are brought into clover crops during the flowering season (Goodwin et al 2011).

So, the objective of this study was to survey Egyptian clover insect visitors specially pollinators and study the population dynamic of the bees during the flowering season and their diurnal activity. Also, make a comparison between seed yield of caged with honeybees, caged without honeybees and non-caged plants, also compared the 1000 seed weight between it.

\section{MATERIALS AND METHODS}

The present study was carried out in the Experimental Farm of Shandaweel Agricultural Research 
Station at Sohag Governorate, during two successive growing seasons of 2017 and 2018. An area of about one Feddan was assigned for different experiments conducted in the current study. By October at the two seasons, the Egyptian clover (Giza 6) seeds were planted with three replicates in complete randomized block design. Experimental plots received regular cultural practices as recommended, except the use of any pesticides.

\section{1) Survey of clover insects}

Direct observations and sweep net collection methods were used to survey certain insects that visited and occurred on plants. Unknown collected adults were identified in the Plant Protection Research Institute, Agriculture Research Centre in Giza, Egypt.

\section{2) Diurnal and seasonal activity of pollinators}

Mean number of pollinators $/ \mathrm{m}^{2} /$ minute visits Egyptian clover florets were calculated by direct observation throughout the blooming periods. Counts were taken twice a week at two hour intervals throughout the day, starting from $7.00 \mathrm{am}$ to $5.00 \mathrm{pm}$. Three replicates were estimated by the aid of one square meter using a wooden frame during the blossom period of Egyptian clover according to McGregor et al 1965.

\section{3) Effect of honeybees on the Egyptian clover seed yield}

The effect of honeybee as pollinator of Egyptian clover was investigated by three treatments. The first was caged with a nucleus hive of honeybees contains about 100 bees with small frame of honey and change it's weekly at night, the second, caged without honeybees and the third was the control without cages.

\section{a) Number of seeds per head}

Average numbers of seeds obtained from 20 heads were counted with the help of seed counter.

\section{b) $\mathbf{1 0 0 0}$-seed weight}

Thousand seeds from each replication of individual treatments thus counted were weighed with the help of an electronic balance to get 1000seeds weight in grams.

For statistical analysis data were analyzed by analysis of variance. When the resulted F-tests were significant, L.S.D test at 0.05 was used to partition the means into significant ranges.

\section{RESULTS AND DISCUSSIONS}

\section{1) Survey of clover insects}

As shown in Table, 1 data were, in descending order to give a general picture for the arthropod specimens that have been identified. However, arthropods listed represent 22 genus of Arthropods belong to 16 families and 7 orders. The identified insect species that listed in this table were classified to Phytophagous, Predator and Nectarivore.

Of all genus, 19 species were identified and the other 3 which were not identified belonging to Syrphus genus, Megachile genus and Orius genus. Order Hymenoptera was most abundant, Lepidoptera, Diptera, Coleoptera, Hemiptra, Neuroptera and Odonata which recorded 29.2,16.7, 16.7,16.7, 12.5, 4.2 and $4.2 \%$, respectively (Fig. 1).

These data were in agreement with those of Mabrouk and Mahbob (2017), who recorded in the Egyptian clover field twenty two insect species, including five species of pests, five species of natural enemies and twelve of pollinators (Phillianthus abdelkader, Polistes gallica, Vespa orientalis, Eumenus maxillosa, Megachile uniformis, Megachile submucida, Megachile muntusemina, Osmia spp., Chalcidoma siculum, Apis mellifera L. Andrena spp. and Ocnera hispida).

Wagan et al (2015) who stated that insect pests on berseem crop, were: aphid, leaf miner, dusky bug, thrips, whitefly, crocket, and cutworm, respectively. Whereas the natural enemies were; rove beetles, lady bird beetle, ant, spider, big eyed, and green lacewing. Hameed et al (2016) revealed that armyworm, Spodoptera exigua, aphid (Sitobian avenae L.) and leaf miner (Aproaerema modicella) are important pests of berseem while the Coccinellids and a Syrphid fly are important predators and honeybee are important pollinators of berseem.

Hesain (2013) recorded eleven species of bees and other insects on the flower of the clover, which are four species from hymenoptera, (Apis melifera, Megachil sp., Halictus sp. and Anderena $s p$.), three species of diptera were (Metasyrphus taeniops, Eristalis anaeus and Episyphus balteatus) and four species of Lepidoptera it were (Lycaeides Melissa (alpime), Autograph gamma L., Colias croceus L., and Artogeia rapa).

Omran (1992) reported that in Qena region (Upper Egypt) Apis mellifera, Megachile submucidae and Andren fuscosa the most abundant hymenopterous visiting the Egyptian clover flowers. 
Role of pollinators on Egyptian clover pollination with special reference to honeybee at 855 Sohag Governorate, Egypt

Table 1. A partial taxonomic list of insects collected from Egyptian clover by using sweep net and direct count methods during 2017 and 2018 flowering seasons.

\begin{tabular}{|c|c|c|c|c|}
\hline Order & Family & Common name & Scientific name & Status \\
\hline $\begin{array}{l}\text { Odonata } \\
\text { Hemiptera }\end{array}$ & $\begin{array}{c}\text { Aeshnidae } \\
\text { Anthocoridae } \\
\text { Pentatomidae } \\
\text { Cicadellidae } \\
\end{array}$ & $\begin{array}{l}\text { Dragon fly } \\
\text { Flower Orius bugs } \\
\text { Green stink bug } \\
\text { Potato leaf hopper }\end{array}$ & $\begin{array}{c}\text { Hemianax ephippiger Burmister } \\
\text { Orius sp. } \\
\text { Nezara vridula L. } \\
\text { Empoasca decipiens Paoli. }\end{array}$ & $\begin{array}{l}\text { Pre. } \\
\text { Pre. } \\
\text { Phyto. } \\
\text { Phyto. }\end{array}$ \\
\hline Neuroptera & Chrysopidae & Green lacewing & Chrysoperla carnea ( Steph.) & Nect.Pre. \\
\hline Lepidoptera & $\begin{array}{l}\text { Pieridae } \\
\text { Lycaenidae } \\
\text { Noctuidae }\end{array}$ & $\begin{array}{l}\text { Small cabbage white } \\
\text { Pea blue butterfly } \\
\text { Cotton leafworm } \\
\text { Beet armyworm }\end{array}$ & $\begin{array}{c}\text { Pieris rapae } \mathrm{L} . \\
\text { Lampides boeticus } \mathrm{L} . \\
\text { Spodoptera littoralis Boisduval } \\
\text { Spodoptera exigua Hubner }\end{array}$ & $\begin{array}{l}\text { Nect., \& Phyto. } \\
\text { Nect., \& Phyto. } \\
\text { Nect., \& Phyto. } \\
\text { Nect., \& Phyto. }\end{array}$ \\
\hline Coleoptera & $\begin{array}{l}\text { Coccinellidae } \\
\text { Curculionidae }\end{array}$ & $\begin{array}{l}\text { Eleven-spot ladybird } \\
\text { Convergent lady beetle } \\
\text { Variegated ladybug } \\
\text { Egyptian alfalfa weevil }\end{array}$ & $\begin{array}{l}\text { Coccinella undecimpunctata L. } \\
\text { Hippodamia convergens Guerin-Me. } \\
\text { Hippodamia variegate Goeze } \\
\text { Hypera brunneipennis Boh. }\end{array}$ & $\begin{array}{l}\text { Pre. } \\
\text { Pre. } \\
\text { Pre. } \\
\text { Pre. }\end{array}$ \\
\hline Hymenoptera & $\begin{array}{c}\text { Apidae } \\
\text { Megachilidae } \\
\text { Sphecidae } \\
\text { Vespidae }\end{array}$ & $\begin{array}{c}\text { Honeybee } \\
\text { Carpenter bee } \\
\text { Alfalfa leafcutter bee } \\
\text { Bee-wolf } \\
\text { Oriental hornet } \\
\text { Paper wasp } \\
\text { Yellow jacket }\end{array}$ & $\begin{array}{c}\text { Apis mellifera L. } \\
\text { Xylocopa pubescens Spinola } \\
\text { Megachile sp. } \\
\text { Philanthus triangulum } \mathrm{F} \text {. } \\
\text { Vespa orientalis } \mathrm{L} . \\
\text { Polistes gallicus } \mathrm{L} . \\
\text { Vespula squamosa D. }\end{array}$ & $\begin{array}{l}\text { Nect. } \\
\text { Nect. } \\
\text { Nect. } \\
\text { Nect.\& Pre. } \\
\text { Nect. \& Pre.. } \\
\text { Nect. } \\
\text { Nect. }\end{array}$ \\
\hline Diptera & $\begin{array}{l}\text { Muscidae } \\
\text { Syrphidae }\end{array}$ & $\begin{array}{c}\text { Orientalis house fly } \\
\text { Hover fly }\end{array}$ & $\begin{array}{c}\text { Musca domestica (Macq.) } \\
\text { Syrphus spp. }\end{array}$ & $\begin{array}{c}\text { Nect. } \\
\text { Nect. \& Pre. }\end{array}$ \\
\hline
\end{tabular}

Nect: Nectarivore, an insects feed on a nectar produced by flowering plants.

Pre: Predator, an insect that feed on other insects or on one of their stages

Phyto: Phytophagous, an insects feeding on plants or plant material.

Nect. \& Phyto: Insects their larvae feeds on the plant and the adult feeds on the nectar.

Nect. \& Pre: Insects, their larvae feeds on the insects and the adult often feeds on the nectar

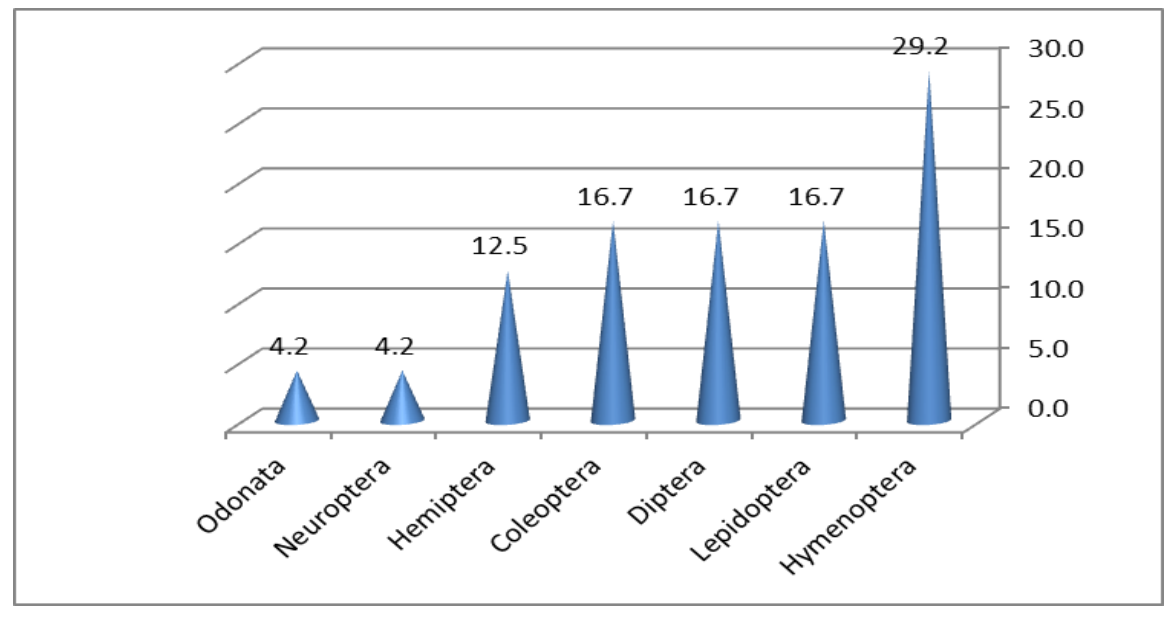

Fig. 1. Percentage of different insects order visit Egyptian clover during 2017 and 2018 
2) Population dynamic of the dominant pollinators visit Egyptian clover flowers

Data graphically in Fig. 2 and 3 illustrated the population densities of $A$. mellifera and Megachile sp. during the two successive Egyptian clover growing seasons, 2016/2017 and 2017/2018.

In the first season 2016/2017 in Fig. 2 the Apis mellifera L. and Megachile sp. were detected during the first week of May. The population began to increase gradually to reach its peak which record- ed 16 and 3 bees $/ \mathrm{m}^{2} / \mathrm{min}$., respectively on the $4^{\text {th }}$ and $3^{\text {rd }}$ week of May respectively and then decreased gradually to the end of the flowering season.

In the second season 2017/2018, the Apis mellifera $L$. and Megachile sp. were detected during the first week of May and then the population began to increase gradually to reach its peak (15 and 5 bees $/ \mathrm{m}^{2} / \mathrm{min}$.), respectively on the $3^{\text {rd }}$ week of May and then decreased gradually to the end of the flowering season (Fig. 3).

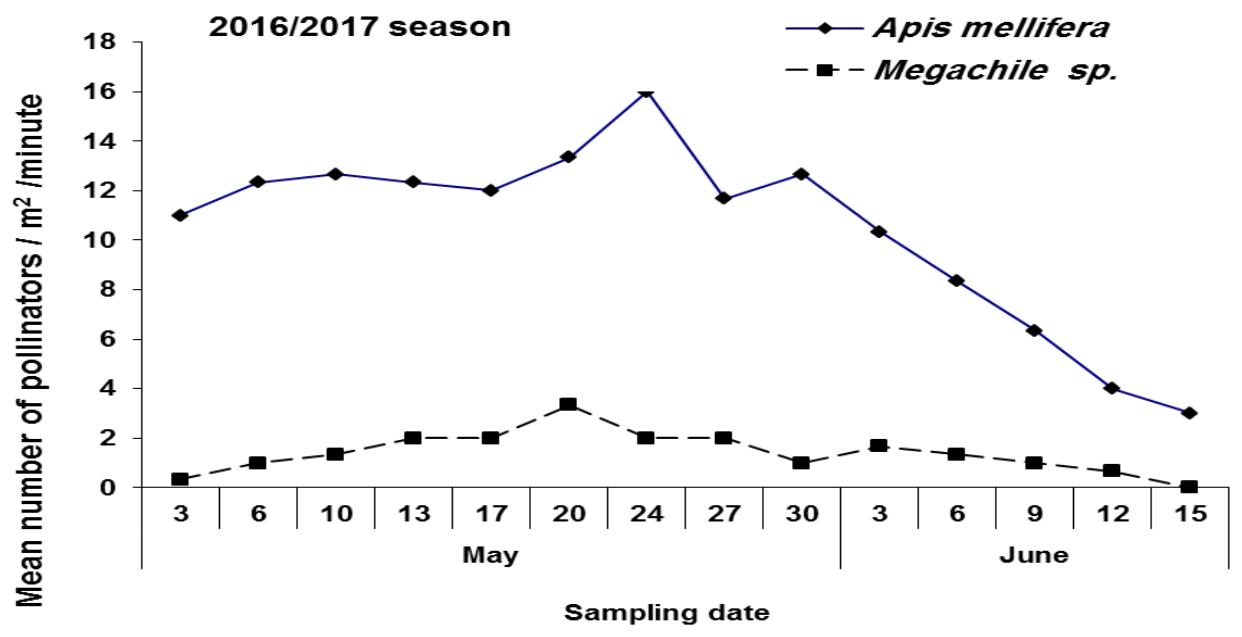

Fig. 2. Population dynamic of the dominant pollinators visited Egyptian clover flowers during 2017 season.

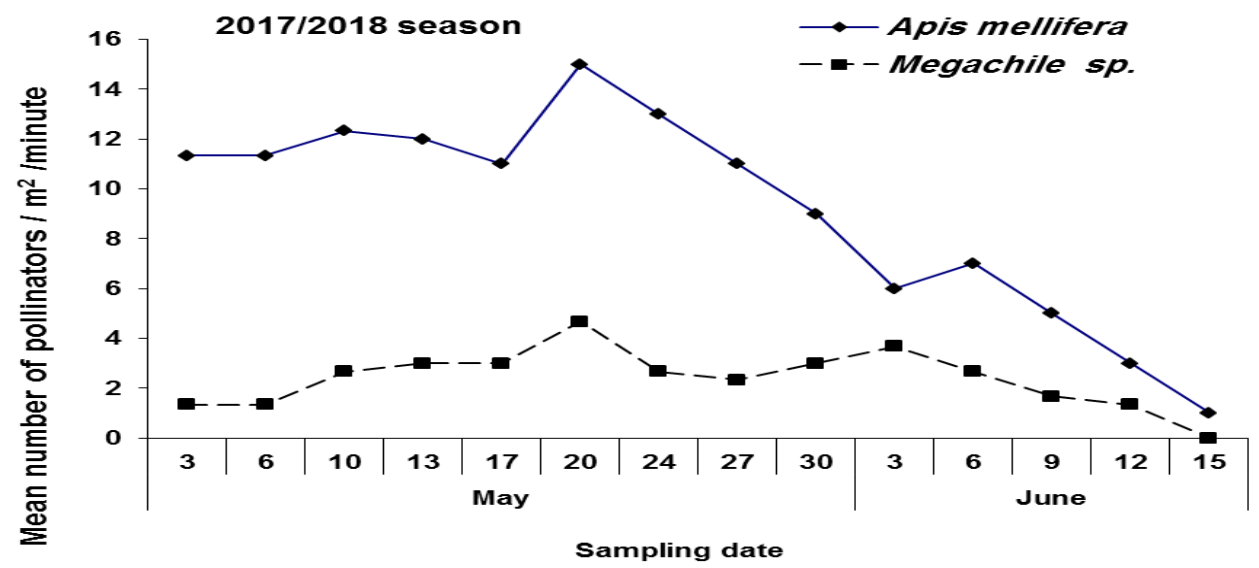

Fig. 3. Population dynamic of the dominant pollinators visited Egyptian clover flowers during 2018 season.

According to Shimaa Essa (2010) bee visitation usually began on clover in the beginning of May till the beginning of June in the two studied seasons. The maximum activity was observed on May $19^{\text {th }}$ (8.03 bees/m2/min.), and reached its low- est activity on June $3^{\text {rd }}(2.26$ bees $/ \mathrm{m} 2 / \mathrm{min}$.) in the $20061^{\text {st }}$, while it was 7.79 bees $/ \mathrm{m} 2 / \mathrm{min}$. on May $17^{\text {th }}$, the minimum was 0.40 bees $/ \mathrm{m} 2 / \mathrm{min}$.) on May $5^{\text {th }}$ in the $2^{\text {nd }}$ season. 


\section{3) Diurnal abundance dynamics of Egyptian clover dominant pollinators}

During the two seasons, Table 2 revealed that the highest activity period for $A$. mellifera was detected at 11:00 a.m. However, the lowest activity was found at 3:00 p.m. and 5:00 p.m. in both seasons respectively with insignificant difference between them in the first season.

Whereas the highest activity period for Megachile sp. was detected at 1:00 p.m., followed signif- icantly by 11:00 a.m. and 3:00 p.m. However, the lower activity was found at 7:00 a.m.

These data were in agreement with those of lbrahim and Selim (1967) reported that foraging activity reached its peak between 10 a.m. to 4 p.m. on Egyptian clover. Shimaa Essa (2010) reported that Egyptian clover showed a variation in number of forages visiting the flowers during the time of the day, but, it reached its peak in the first season at 8 a.m. and 10 a.m. In the second season it was observed at 2 p.m. and 4 p.m.

Table 2. Number of bees $/ \mathrm{m}^{2} / \mathrm{min}$. on Egyptian clover flowers at different hours of the day during 2017 and 2018 seasons.

\begin{tabular}{|c|c|c|c|c|c|c|c|c|}
\hline Pollinator & Season & $\begin{array}{c}\mathbf{7 : 0 0} \\
\text { a.m. }\end{array}$ & $\begin{array}{c}\mathbf{9 : 0 0} \\
\text { a.m. }\end{array}$ & $\begin{array}{c}\mathbf{1 1 : 0 0} \\
\text { a.m. }\end{array}$ & $\begin{array}{c}\mathbf{1 : 0 0} \\
\text { p.m. }\end{array}$ & $\begin{array}{c}\mathbf{3 : 0 0} \\
\text { p.m. }\end{array}$ & $\begin{array}{c}\mathbf{5 : 0 0} \\
\text { p.m. }\end{array}$ & $\begin{array}{c}\text { F. val- } \\
\text { ue }\end{array}$ \\
\hline \multirow{2}{*}{ A. mellifera } & $\mathbf{2 0 1 6 / 1 7}$ & $7.10 \mathrm{~d}$ & $8.05 \mathrm{c}$ & $10.43 \mathrm{a}$ & $9.21 \mathrm{~b}$ & $4.07 \mathrm{e}$ & $4.45 \mathrm{e}$ & 406.46 \\
& $\mathbf{2 0 1 7 / 1 8}$ & $6.45 \mathrm{c}$ & $7.17 \mathrm{~b}$ & $9.14 \mathrm{a}$ & $7.00 \mathrm{~b}$ & $4.24 \mathrm{~d}$ & $2.40 \mathrm{e}$ & 251.65 \\
\hline $\begin{array}{c}\text { Megachile } \\
\text { sp. }\end{array}$ & $\mathbf{2 0 1 6 / 1 7}$ & $0.24 \mathrm{~d}$ & $0.64 \mathrm{c}$ & $1.40 \mathrm{~b}$ & $2.09 \mathrm{a}$ & $1.59 \mathrm{~b}$ & $0.57 \mathrm{c}$ & 109.47 \\
\hline
\end{tabular}

Means in the same row followed by different letters are significantly different (L.S.D Test at 0.05).

3) Effect of honeybees on the Egyptian clover seed yield

\section{a) Number of seeds per head}

The analysis of the data in Fig. 4 revealed that the insect pollination had a significant effect on the number of seeds per head in the two seasons of the study were 52.13 and 55.60 , respectively. The non-caged treatment produced the highest mean number of seeds per head followed by the caged with honeybee treatment were 48.15 and 43.85 seeds / head, respectively, in 2016/2017 season, and 51.10 and 46.10 seeds / head, respectively, in $2017 / 2018$ season. On the other hand the lowest mean was recorded in a cage without honeybee treatment were 13.20 and 10.85 seeds/head in both seasons, respectively. From the above data, it was clear that the wild pollinators may play an essential role in clover pollination under experimental conditions.

These data were in agreement with those of Bondok et al (2016) found that Maximum Egyptian clover seed yield (2346.6 seeds/40 head) was observed with honey bee pollination six combs followed by four combs (2250.0 seeds) and two combs (1826.6 seeds). Still the lowest seed yield was found in field without insect pollinators.

Jat et al (2014b) observed that maximum seed yield (2662.3 seeds) was observed in honey bee pollination with 8 combs followed by 4 combs (2373.8 seeds), open pollination (2316.3 seeds) and 2 combs (2235.5 seeds). Still lower yield of (2103.0 seeds) was found in hand pollination treatment that was significantly higher than that without insect pollinator's treatment (1114.2 seeds).

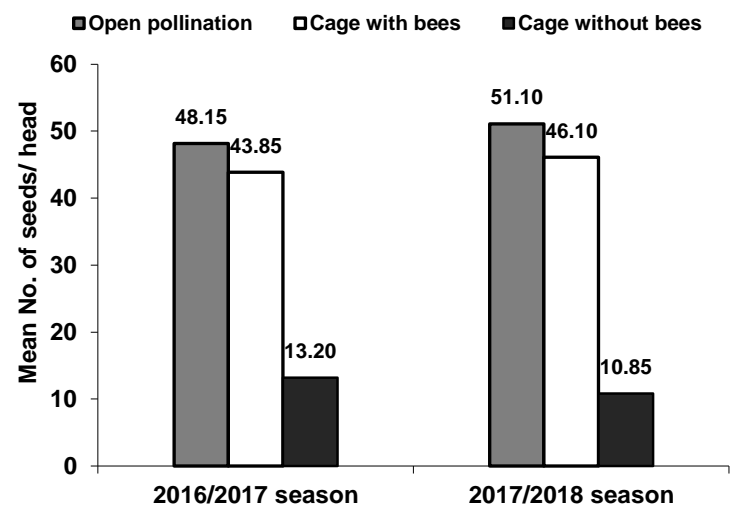

Fig. 4. Mean number of Egyptian clover seeds/ head at different modes of pollination during 2017 and 2018 seasons.

According to Cecen et al (2007) the highest seed yield of white clover, Trifolium repens L. was found in the caged honeybee treatment (46.2 $\mathrm{kg} / \mathrm{ha}$ ) followed by caged bumblebees $(37.3 \mathrm{~kg} / \mathrm{ha})$, 
open-pollinated $25.7 \mathrm{~kg} / \mathrm{ha}$ ) and pollinator excluded (1.37kg/ha).

Sharma and Singh (2003) found that seed yield in open pollinated plants ranged from 19.670.5 seeds per flower head compared to only 0.3 0.6 seeds where insects were excluded (caged).

\section{b) 1000 -seed weight}

Data illustrated in Fig. 5 revealed that the insect pollination had a significantly effect on the number of seeds per head in the two seasons of the study ( $F$. value was 9.92 and 16.11 , respectively). The non.-caged treatment produced the highest mean number of seeds per head followed insignificantly by the caged with honeybee treatment with 3.50 and 3.40 seeds/ head, respectively, in 2016/2017 season, and 3.90 and 3.80 seeds/ head, respectively, in 2017/2018 season. On the other hand, the lowest mean was recorded in a cage without honeybee treatment with 2.75 and 2.55 seeds / head in both seasons, respectively. From the above data, it was clear that the honeybee was efficient pollinator of clover under experiment conditions.

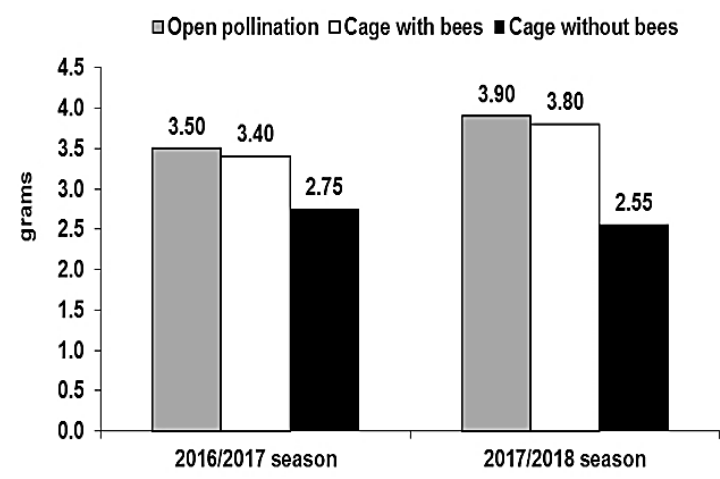

Fig. 5. Mean weight $(\mathrm{g})$ of 1000 seeds at different modes of pollination during 2017 and 2018 seasons.

These data were in agreement with those of Bondok et al (2016) whom founded that minimum 1000-seed weight with without insect pollination was observed $(2.56 \mathrm{~g})$. The 1000 seed weight of bee Pollination-four Frame, six Frame and, bee Pollination two Frame were $3.56,3.30,3.80 \mathrm{~g}$, respectively. Also, Jat et al (2014b) observed that Minimum 1000-seed weight was in without insect pollination $(2.64 \mathrm{~g})$. Whereas the seed weight of bee pollination four frame (3.30) Hand Pollination (3.20) bee pollination two frame (3.17) and open pollination (3.03), the heaviest seeds were record- ed in, bee pollination eight frame (3.62 g/1000 grains). Singh et al (2012) reported that 1000seed weight $(2.47 \mathrm{~g})$ in plots caged with A.mellifera colony compared to without insect pollination (2.22g).

\section{REFERENCES}

Bakheit, B.R. 2013. Egyptian clover, (Trifolium alexandrinum L.) Breeding in Egypt: A Review. Asian J. of Crop Science 5(4), 325-337.

Bezabih, G. and Gebretsadikan K. 2014. Managed honeybees (Apis mellifera L.) increase onions (Alliun cepa) seed yield and quality. Livestock Res. Rural Develop., 26(1).

Bondok, A.T., El Nahrawy M., Shereen and Asmaa A. Esa 2016. Effect of honeybee pollination on Egyptian clover seed yield. Alex. Sci. Exch. J. 37(3), 451-456.

Cecen, S., Gosterit A. and Gurel F. 2007. Pollination effects of the bumblebee and honeybee on white clover (Trifolium repens L.) seed production. J. Apic. Res. 46(2), 69-72.

El-Nahrawy, M.A.Z. 2005. The vital role of Egyptian clover in agriculture. Proceedings of the $11^{\text {th }}$ Conference of Agronomy, November 15-16, Assiut University, Assiut, Egypt, pp. 55-62.

Essa, Shimaa, Y. 2010. Studies on the foraging activity of honey bee on some field crops in sohag region. Thesis, Fac. Agric. Minia .Univ. 171 p.

Goodwin, R.M., Cox H.M., Taylor M.A., Evans L.J. and McBrydie H.M. 2011. Number of honey bee visits required to fully pollinate white clover (Trifolium repens) seed crops in Canterbury, New Zealand. New Zealand Journal of Crop and Horticultural Science, 39(1), 7-19.

Hameed, A., Karar H., Muhammad N. and Kainth R.A. 2016. Varietal response to population fluctuation of insect pests, predators and pollinator fauna associated with berseem (Trifolium alexandrinum L.) crop. Pakistan J. Zool., 48(3), 729-734.

Hesain, H.M. 2013. Daily activity of some local pollinators for Clover crop Trifolium alexandrinum L. J. of Babylon Univ. Pure and Applied Sciences/ 3 (21), 901-909.

Ibrahim, S.H. and Sleim H.A. 1967. Studies on pollen gathering activity of honey bees from broad bean (Vicia faba L.). Agric. Res. Rev. 45 (2), 147-161.

Jat M.K., Chaudhary O., Kaushik H.D. and Tetarwal A.S. 2014a. Floral biology studies of 
Role of pollinators on Egyptian clover pollination with special reference to honeybee at 859 Sohag Governorate, Egypt

Egyptian clover, Trifolium alexandrinum L. Research in Plant Biology, 4(3), 16-21.

Jat M.K., Chaudhary O.P., Kaushik H.D., Yadav S. and Tetarwal A.S. 2014b. Effect of different modes of pollination on quantitative and qualitative parameters of Egyptian clover, Trifolium alexandrium L. J. of Applied and Natural Science 6(2), $605-610$.

Klein, A.M., Vaissiere B.E. and Cane J.H. 2007. Importance of pollinators in changing landscapes for world crops. Proceedings of the Royal Society, 274, 303-313.

Mabrouk1, M. S. O. and M. A. Mahbob 2017. Survey of the most common insect species on some foraging crops of honeybees in Dakhla Oasis, New Valley Governorate, Egypt. J. Eco. Heal. Env. 5(1), 35-40.

McGregor, S.E., Levin M.D. and Forter R.E. 1965. Honeybee visitors and fruit set of cantaloupes. J. Econ. Entomol. 58, 968-970.
Morse, R.A. and N.W. Calderone 2000. The value of honey bee pollination the United States. Bee Cult 128, 1-15.

Omran, N.S.M. 1992. Studies on the insect pollinators of some field crops in Quena region (Upper Egypt). M.Sc. Thesis, Fac. Agric. Minia .Univ.128p.

Sharma, S.K. and Singh J.R. 2003. Pollination efficiency of Apis sp. on Egyptian clover (Trifolium alexandrinum L.). Forage Research, 28(4), 218-219.

Singh, J., Yadav S. and Chhuneja P.K. 2012. Quantitative and qualitative enhancement in Trifolium alexandrium L. seed production through pollination by Apis mellifera L. Indian J.I of Applied Entomology, 26(1), 50-53.

Wagan, A.T., Zahoor H.H. and Wagan A. 2015. Insect Pests and Natural Enemies Associated with Berseem (Trifolium alexandrinum L.) in Cotton Field. J. of Biology, Agriculture and Healthcare. 5 (3), 129-133. 

المؤتمر الرابع عشر لبحوث التنمية الزراعية،

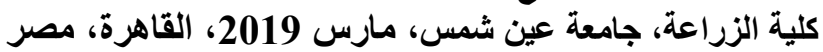

مجلا(27)، عدد (1)، عدد خاص مارس، مارس، 860-853، 2019

إيهاب وفيق زيدان 1- أحمد محمود عبد اللطيف²- أحمد رمضان مزيد1 1

1- قسم بحوث النحل- معهز بحوث وقاية النباتات- مركز البحوث الزراعية- مصر لئر

2- قسم بحوث العلف- معهد بحوث المحاصيل الحقلية- مركز البحوث الزراعية- مصر مركز

"Corresponding author: ar.mazeed@gmail.com

كع عدم وجود فرق معنوي في الموسم الأول، في حين

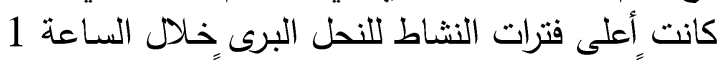

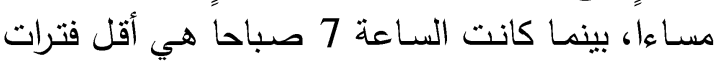
النشاط لهذه الحشرة خلاءل موسمي الدراسة.

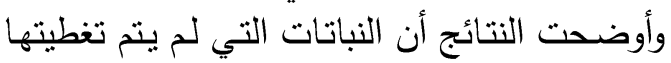

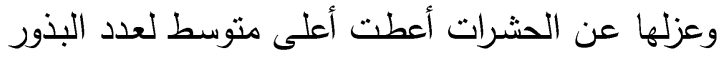

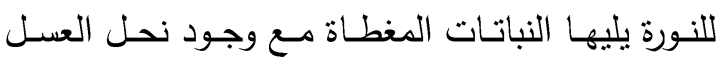
وكانت النباتات المغطاة و بدون نحل العسل هي الند الأقل

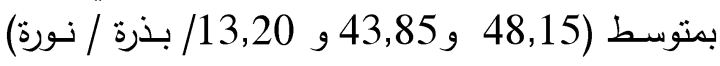

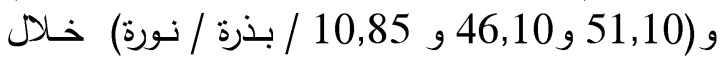
موسمى الدراسة على الترتيبٍ.

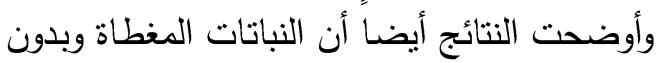

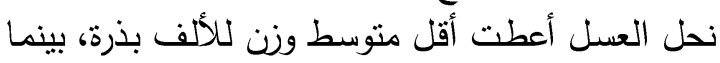

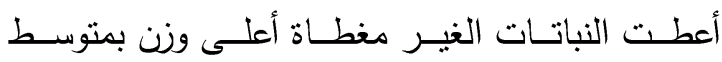

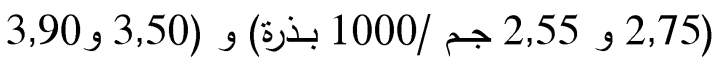
جم/1000 بذرة) خلال موسمي الدراسة على الترتيب.

الكلمــات الداتــة: البرسـيم المصــري، محصــول البـذور،

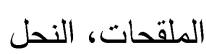

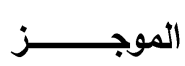

تعدف الدراسـة إلى حصر أنواع الحشرات الملقحة

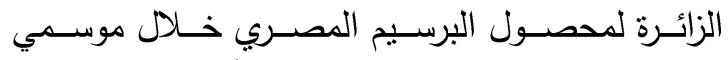

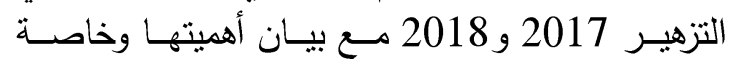

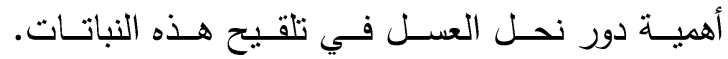

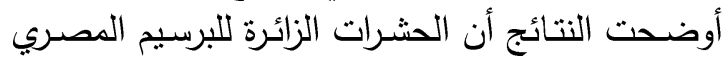

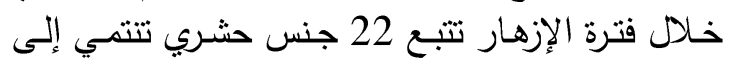

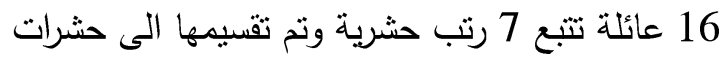

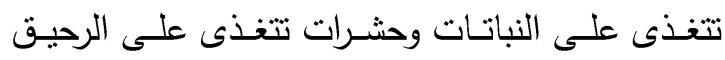

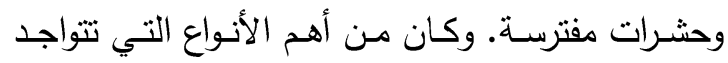

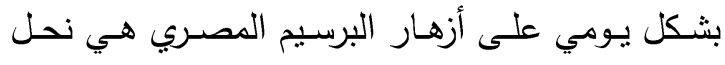

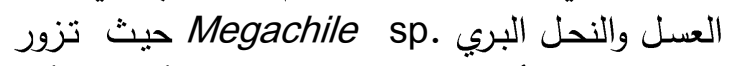

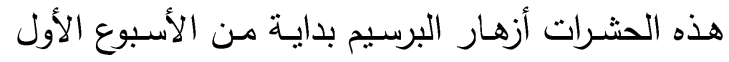

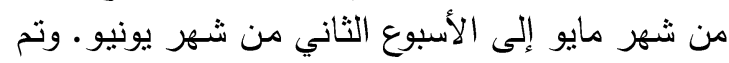

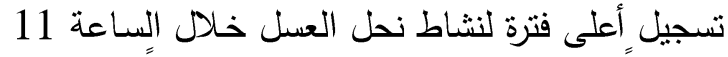

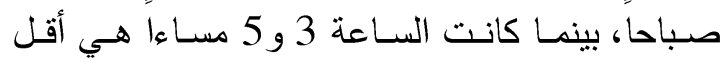
فترات النشاط الحشرة في موسمي الزراعة علي التوالي 